підготовки вчителів початкових класів в умовах інформаційно-комунікаційного педагогічного середовища: [монографія] / Л. Є. Петухова. - Херсон : Айлант, 2007. - 220 с.

\title{
УДОСКОНАЛЕННЯ ПЕДАГОГІЧНОЇ МАЙСТЕРНОСТІ ВИКЛАДАЧІВ ІНОЗЕМНОЇ МОВИ ЩОДО ОРГАНІЗАЦЇ̈ НАВЧАЛЬНОГО ПРОЦЕСУ НА ОСНОВІ ІННОВАЦИИНИХ ІНФОРМАЦІЙНИХ ТЕХНОЛОГІЙ
}

Побережна Н. О. Удосконалення педагогічної майстерності викладачів іноземної мови щодо організації навчального процесу на основі інноваційних інформаційних технологій.

У статті розглянуто дидактичні й методичні аспекти, що характеризують сучасну педагогічну систему, а також педагогічні особливості іiї організації під час вивчення іноземної мови в інформаційно-освітньому середовищі (IOC).

Ключові слова: педагогічна майстерність, інформаційна компетентність, інформаційно-освітне середовище вищого навчального закладу.

Побережная Н. O. Усовершенствование педагогического мастерства преподавателей иностранных языков в организации учебного процесса на основе инновационных информационных технологий.

В статье рассмотрены дидактические и методические аспекты, характеризующие современную педагогическую систему, а также педагогические особенности ее организации при обучении иностранному языку в информационно- образовательной среде (ИОС).

Ключевые слова: педагогическое мастерство, информационная компетентность, информационно-образовательная среда высшего учебного заведения.

Poberezhna N. O. Improvement of pedagogical skills of teachers of a foreign language in reference to training process, based on innovative information technologies.

The article deals with didactic and methodological aspects of modern pedagogical system and pedagogical activity in teaching foreign languages in the conditions of informatively-educational environment.

Key words: pedagogical excellence, information competence, informatively-educational environment of higher educational establishment.

Сучасна система освіти зазнає значних змін, зумовлених, як слушно зауважує А. Тряпельникова, «незворотними поступальними чинниками» [14], до яких ми відносимо, по-перше, бурхливий розвиток інформаційно-телекомунікаційних технологій, по-друге, зміну статусу англійської мови, який став мовою міжнародного спілкування, без володіння яким нині не мислиться успішна професійна діяльність й ефективна професійна комунікація 3 представниками різних лінгвосоціумов.

Mema cmammi - проаналізувати дидактичні й методичні аспекти, що характеризують сучасну педагогічну систему в інформаційно-освітньому середовищі (IOC); виявити педагогічні особливості іiї організації під час навчання іноземної мови.

У науковій літературі створення високоякісної та високотехнологічної IOC розглядається переважно як досить складне технічне завдання, що дозволяє докорінно модернізувати технологічний базис системи освіти загалом. Водночас не можна заперечувати факт, що створення IOC - це не тільки становить виключно технічне завдання. Задля їі створення, розвитку й експлуатації необхідно повністю задіяти науковометодичний, організаційний і педагогічний потенціал усієї системи освіти. У зв'язку з цим необхідно враховувати також і проблеми педагогіки в умовах функціонування сучасних інформаційно-освітніх середовищ. 
Створення інформаційно-освітнього середовища, стало предметом низки досліджень (В. Бикова， С. Григор'єва， I. Захарової, М. Козяра, С. Сисоєвої, С. Панюкова, С. Позднякова, Є. Полат, І. Роберт). Автори пропонують різні підходи до розуміння сутності і структури інформаційно-освітнього середовища (IOC).

Аналіз численних, іноді діаметрально протилежних визначень IOC дозволяє зробити висновок, що це - сукупність (скоріше, система) інформаційної, технічної й навчальнометодичної підсистем, що цілеспрямовано забезпечують навчальний процес, а також його учасників. Теоретичне ядро всієї IOC становить саме педагогічна система. Більшість науковців схиляються до позиції про актуальність розроблення нового напрямку педагогічної науки «Електронна педагогіка», що досліджує педагогічні процеси в цьому новоутворенні, умовно позначеному як IOC. Структура педагогічної системи відкритої освіти - це логічне продовження і розвиток традиційної системи. Однак змінюється зміст елементів цієї системи: цілей, змісту освіти й людського чинника - навчається і навчають.

Мета сучасної освіти - це система знань, умінь і навичок, що формуються відповідно до моделі фахівця, яка визначається відповідними освітніми стандартами: розвиток тих здібностей особистості, які потрібні їй самій і суспільству; включення соціально-ціннісної активності особистості; забезпечення можливостей ефективної самоосвіти (зокрема підвищення кваліфікації) за межами інституціальних освітніх систем).

За цих умов принципово змінюються методи роботи педагога i, що найголовніше, іiі результати під час здійснення навчального процесу в умовах IOC. На цьому наголошують багато вітчизняних науковців: Н. Голівер, В. Монахов, С. Панюкова, М. Потєв, І. Роберт, Є. Скибицький, М. Чванова, Ю. Шафрін та інші. Зокрема, Н. Голівер наводить відмінні риси педагогічного процесу з використанням нових інформаційних технологій, а саме: збільшення питомої ваги проектної (творчої) роботи студентів і зростання обсягу роботи, що виконується індивідуально і в парах; зменшення ролі педагога як «джерела знань» і зростання його ролі як «вихователя і наставника»; зростаюча готовність тих, хто навчається, нести відповідальність за результати свого навчання [2, с. 9].

У цьому розумінні питання педагогічної майстерності викладача потребує особливої уваги. Перш ніж звернутися безпосередньо до складників педагогічної майстерності викладачів на основі здійснення навчального процесу в умовах IOC, розглянемо розроблені на сучасному етапі розвитку педагогічної думки підходи щодо визначення педагогічної майстерності та іiї складників.

Педагогічна майстерність, на думку С. Гончаренка, це - «... характеристика високого рівня педагогічної діяльності. Критеріями педагогічної майстерності виступають такі ознаки його діяльності, як гуманність, науковість, педагогічна доцільність, оптимальний характер, результативність, демократичність, творчість (оригінальність)» [3, с. 251].

А. Щербаков розуміє педагогічну майстерність як «синтез наукових знань, умінь i навичок методичного мистецтва і особистих якостей педагога» [15].

У вітчизняній педагогічній науці найгрунтовніше до цієї проблеми підійшли науковці та педагоги кафедри педагогічної майстерності Полтавського педагогічного інституту імені В. Г. Короленка на чолі з академіком АПН України І. Зязюном.

Основні положення їхніх напрацювань містяться в навчальному посібнику «Основи педагогічної майстерності» [6] і підручнику «Педагогічна майстерність» [7].

Автори згаданого підручника розглядають педагогічну майстерність «як найвищий рівень педагогічної діяльності (якщо характеризуються якісні показники результату), вияв творчої активності особистості педагога (якщо характеризується психологічний механізм успішної діяльності)» [7]. Як педагогічну категорію вони їі визначають так: «Педагогічна майстерність - це комплекс властивостей особистості, що забезпечує високий рівень самоорганізації професійної діяльності на рефлексивній основі» [7].

Найважливішими властивостями особистості педагога науковці вважають: гуманістичну спрямованість діяльності педагога, його професійну компетентність; педагогічні здібності, педагогічну техніку. 
Відповідно до окреслених структурних елементів визначаються кілька рівнів оволодіння педагогічною майстерністю:

- $\quad$ елементарний рівень - педагог має лиш окремі якості професійної діяльності;

- базовий рівень - педагог володіє основами педагогічної майстерності (це рівень, характерний для випускників педагогічних інститутів);

- досконалий рівень - характеризується чіткою спрямованістю дій педагога, їхньою високою якістю, діалогічною взаємодією у спілкуванні;

- творчий рівень характеризується ініціативністю, творчим підходом до професійної діяльності.

Перераховані ознаки педагогічної майстерності не викликають заперечень, між тим, на наш погляд, якщо ми говоримо про складники педагогічної майстерності в умовах здійснення навчального процесу в IOC, необхідною компетенцією викладача на сучасному рівні розвитку освіти постає інформаційно-комунікаційна компетенція, яку можна визначити як «готовність i здатність методично грамотно використовувати дидактичні можливості інформаційно-комунікаційних технологій під час здійснення педагогічної діяльності в умовах IOC».

Рівень професіоналізму будь-якого фахівця, i, зокрема, викладача ВН3, характеризується умінням працювати з інформацією, наявністю практичних навичок іiі виокремлення, структурування, оброблення і передавання; умінням оперативно приймати аргументовані рішення на іiі основі і модифікувати цілі і зміст навчання. Головне місце в розв'язанні цих завдань займають інформаційно-комунікаційні технології. Отже, до системи компетенцій викладача ВНЗ на сучасному етапі входить інформаційнокомунікаційна компетенція як складник педагогічної майстерності викладача за умов здійснення навчального процесу в IOC.

Розвиток інформаційно-комп'ютерних технологій відбувається динамічно, стандартний набір навчальних комп'ютерних технології практично повністю оновлюється кожні п’ять років. Технології, які використовувалися на початку XXI століття, відходять у минуле, поступаючись місцем новітнім засобам передавання й організації інформації. Покоління Інтернет-технологій WEB 1.0 змінилося на WEB 2.0, і на порозі вже третє покоління. Викладач ВН3, особливо іноземної мови і культури, не може залишатися осторонь і не бути в курсі змін, що відбуваються, оскільки технології змінюють не тільки способи і методи навчання мов, технології сьогодення змінюють структуру суспільства і суспільних відносин, що відбивається на механізмах культури i мови, i ці зміни мають також відповідно транслюватися в навчальному процесі навчання іноземних мов.

Проблеми застосування інформаційних технологій в успішному навчанні іноземних мов розглядаються в працях Є. Полат [9], А. Трутнєва [13]. Науковці підкреслюють, що комп'ютерні технології $є$ ефективним виховним, методичним і дидактичним засобом підвищення якості навчального процесу. Зокрема, інформаційні технології під час вивчення іноземної мови сприяють: індивідуалізації навчальної діяльності, максимальній iii самостійності, творчому характеру; максимальній комфортності, відповідності темпу навчальної діяльності індивідуальним особливостям студентів, подоланню комунікативного бар'єру; формуванню в тих, хто навчається, комунікативних навичок, культури спілкування; формуванню навичок дослідницької діяльності; створенню справжнього мовного середовища, насамперед, за рахунок телекомунікаційних контактів із носіями мови; створенню підвищеної мотивації до оволодіння мовленнєвими навичками та використання їх у реальних міжособистісних навчальних і ділових контактах.

Водночас дидактичний потенціал інформаційних технологій та методика їх застосування для цілей навчання іноземних мов ще недостатньо вивчені. Нині актуальними є розробки інформаційних ресурсів в електронному вигляді для навчання іноземних мов, однак через відсутність наукової і методологічної бази, чіткого уявлення про технічні і методичні проблеми застосування інноваційних інформаційних технологій 
у процесі навчання іноземних мов досягнуті результати мають фрагментарний характер і часткові рішення.

До завдань дослідження в межах завдань статті входить виявлення комплексу компетенцій у складі професійної інформаційної компетенції викладача іноземних мов 3 урахуванням сучасної мети навчання і потреб студентів для ефективного навчання іноземних мов.

Специфіка іноземної мови як предмета безпосередньо визначає як характер й особливості освітнього середовища, так і інформаційно-комунікаційну компетенцію викладача як складника його педагогічної майстерності. Освітній процес в такому середовищі слід здійснювати в діалозі двох світів - світу іноземної і світу рідної культури. Визначальною рисою такого освітнього середовища є методична домінанта, орієнтована на розвиток студентів як суб'єктів своєї навчальної діяльності та діалогу культур.

Оптимальний варіант оволодіння іноземною мовою в традиційних умовах не мислиться без навчання в природному мовному середовищі. Так само, як неможливо навчитися плавати без водного середовища; без відповідного мовного середовища не домогтися сформованості навичок ефективного іншомовного міжкультурного спілкування. Водночас в новітньому інформаційно-освітньому середовищі це не означає неможливість ефективного навчання мови та іншомовної культури поза їх природнім середовищем, оскільки інноваційні інформаційні технології, за словами Н. Сірники, «організовують спілкування, яке відбувається майже безпосередньо з носіями мови» [11. с. 47]. Головна перевага інноваційних технічних засобів навчання полягає, як уважаємо, в тому, що вони $\epsilon$ джерелом автентичності, несуть в собі живу сучасну мову і надають справжнє уявлення про культуру. Саме завдяки цьому складовому елементу і використанню адекватної методики під час навчання іноземної мови інформаційно-освітнє середовище може сприяти створенню оптимальних умов для підготовки фахівця, який володіє іноземною мовою як засобом міжкультурного спілкування.

На ролі автентичних відео- та мультимедійних матеріалів в організації освітнього середовища наголошено у відповідній методиці. Важливою властивістю мультимедіа $€$ інтерактивність, що надає користувачеві можливість зворотного зв'язку [8, с. 168]. Стосовно мультимедійних засобів навчання можна нагадати те, що писав Я. Коменський у своїй праці «Велика дидактика»: «...Усе, що тільки можна, надавати для сприйняття чуттям, а саме: видиме - для сприймання зором, чутне - слухом, запахи - нюхом, доступне дотикові - через дотик. Якщо будь-які предмети відразу можна сприйняти кількома чуттями, нехай вони відразу сприймаються кількома чуттями...».

Застосування засобів навчання нового покоління може бути ефективним тільки за умов правильного обрання програмно-апаратної реалізації засобу залежно від організаційної форми навчання, у якій вони застосовуються.

Дидактична функція інформаційних технологій виявляється у здійсненні за допомогою інтелектуальних комп'ютерних систем та інформаційних мереж процедур та операцій, які впливають на пізнання та сприяють збільшенню обсягу нових знань. Отже, інформаційні технології докорінно змінюють не тільки освітні, але й духовні орієнтири, спрямовані на вироблення знань, виконуючи те, чого ніколи не здійснювали колишні пристрої й технології. Тому інформаційне суспільство також досить часто називають «суспільством, яке навчається».

Перехід до нової парадигми освіти, у центрі якої перебуває особистість студента i культура як його домінанта, вимагає такого підходу до організації освітнього середовища в навчанні іноземних мов із залученням інформаційних технологій і глобального комунікаційного простору, коли створюються умови збалансованого, рівномірного функціонування всіх іiі структурних компонентів, а зміст навчання спрямоване на засвоєння соціокультурних аспектів спілкування на мові, що вивчається, вивчення менталітету, стосунків, поведінки, цінностей, релевантних культурі мови, що вивчається. Особливість IOC для навчання іноземних мов полягає в тому, що вона реалізується у 
специфічному навчальному мовному середовищі, моделюється викладачем із використанням спеціально розроблених навчальних матеріалів і комплексу інстументов, що дозволяють ефективно організовувати іншомовну комунікацію учасників спілкування. Її функціонування забезпечується взаємодією трьох складників: змістовної, організаційної й технологічної.

Здійснивши аналіз характерних особливостей сучасної системи освіти з використанням інформаційних технологій, ми дійшли висновку, що освітнє середовище нового типу є засобом й умовою комунікативно-орієнтованого навчання іноземних мов, в основу якого покладено модель реального спілкування й новітні засоби й методи навчання. Ураховуючи, що процес реального мовного взаємодії детермінує певну ситуацію під час навчання іноземних мов поза природним мовним і культурним середовищем, викладачі $\epsilon$ проектувальниками інформаційно-освітнього середовища навчання і повинні намагатися моделювати іiї з урахуванням принципу автентичності.

У складі професійної інформаційної компетенції викладача вишу щодо ефективної організації навчального процесу на основі інноваційних інформаційних технологій ми виокремлюємо такий комплекс компетенцій як основу для удосконалення педагогічної майстерності викладачів іноземної мови: знання моделей, можливостей і параметрів процесу навчання іноземних мов на основі інформаційно-комунікаційних технологій; використання інноваційних засобів ІКТ останнього покоління у професійній діяльності викладача іноземної мови, який працює в системі вищої освіти; володіння навичками автоматизації оброблення навчальної інформації та іiі стандартизації, а також творчими навичками подання навчального матеріалу і розроблення навчальних курсів на основі IКТ; знання основних функцій освітнього електронного середовища навчання мов і культур, принципів його створення й управління; володіння сучасними прийомами і методами використання засобів ІКТ під час проведення різного роду занять, у розробленні дослідницьких проектів, у різних видах навчальної та виховної діяльності; знання можливостей практичної реалізації навчання, зорієнтованого на розвиток особистості студента в умовах використання технологій мультимедіа (в перспективі «Віртуальна реальність»), систем штучного інтелекту, інформаційних систем, що функціонують на базі IКТ, що забезпечують автоматизацію введення, накопичення, оброблення, передавання, оперативного управління інформацією.

Окреслений комплекс компетенцій у складі професійної інформаційної компетенції викладача іноземних мов дозволив виокремити такі структурні елементи розглядуваного комплексу:

1. Компетентнісний підхід до навчання іноземних мов. Європейський мовний портфель.

2. Комплексні багаторівневі програмні пакети навчання мов (як для організації аудиторної, так і самостійної роботи студентів).

3. Практичне використання на уроці іноземної мови Інтернет-ресурсів покоління WEB 2.0 для навчання мов (спеціалізовані та неспеціалізовані ресурси; розроблення аудиторного та дистанційного Інтернет-уроку; використання подкастів та інших мультимедійних ресурсів для навчання мов).

4. Сучасні веб-орієнтовані програмні засоби - електронні навчальні оболонки (LMS). LMS у побудові дистанційних курсів.

5. Модульне навчальне середовище Moodle як основа дистанційного навчання мовам i засіб підтримки аудиторних занять.

6. Веб-орієнтований електронний НМК (з урахуванням лінгвометодичних принципів побудови електронного навчального курсу та дистанційного курсу, статичні й інтерактивні засоби створення курсу).

7. Електронне портфоліо студента і викладача як засіб індивідуалізації навчання мов і культурам (Mahara як один із сучасних засобів створення системи е-портфоліо на основі міжнародних стандартів). 
8. Автоматизація тестування засобами IKT (засоби Moodle для організації тестування; створення тестів у програмі HotPotato; Інтернет-сервіси для створення онлайн-тестів).

9. Сервіси ІКТ покоління 2.0 в навчанні мов та культури (сервіси доставки повідомлень у реальному часі і VoIP технології в навчанні мов; Skype, ICQ, MSN; використання блогів і вікі; Вікіпедія як засіб навчання).

10. Соціальні мережі та їх лінгводидактичні можливості. Використання сервісів Google в навчанні мов. Google Wave, Google Calendar, Google maps, Google Groups.

Беззаперечно, умови розвитку інноваційних інформаційних технологій сучасного суспільства диктують необхідність у розвитку і формуванні нових компетенцій викладачів ВН3, за допомогою яких вони можуть найбільш ефективно впоратися із завданням організації результативного навчального процесу, стандартизувати й автоматизувати рутинні освітні операції, а також відкрити можливості для пошуку нових творчих методів і технологій навчання мов.

Отже, незважаючи на те, що в центрі процесу навчання з використанням інформаційнокомунікаційних технологій перебуває самостійна пізнавальна діяльність студентів і їхня самостійна робота щодо формування необхідних навичок, умінь i професійних компетенцій, успішність і якість навчання з використанням IКТ значною мірою залежать від ефективності організації IOC та методичної якості використовуваних матеріалів, а також керівництва, майстерності викладачів, які моделюють іiі згідно 3 педагогічною метою освіти.

\section{Література}

1. Биков В. Ю. Теоретико-методологічні засади моделювання навчального середовища сучасних педагогічних систем / В. Ю. Биков, Ю. О. Жук // Проблеми та перспективи формування національної гуманітарно-технічної еліти : [зб. наук. праць]. - 2003. - №1(5). - С. 64-76. 2. Голівер Н. О. Дидактичні умови використання комп'ютерних технологій у процесі навчання студентів вищих технічних закладів : автореф. дис. на здобуття наукового ступеня канд. пед. наук / Н. О. Голівер. Луцьк, 2005. - С. 9. 3. Гончаренко С. У. Український педагогічний словник : [для педагогівпрактиків, наукових працівників, студентів і аспірантів, вихователів, батьків] / С. У. Гончаренко. К. : Либідь, 1997. - 376с. 4. Единное окно доступа к образовательным ресурсам. Глоссарий педагогических терминов[Электронный ресурс].- Режим доступа: http://www.window.edu.ru/window/ glossary 5. Зязюн I. А. Естетичні регулятиви педагогічної майстерності : [матеріали міжнар. наук.практ. конф., (Вінниця 23-24 травня 2006 р.)] / І. А. Зязюн. - Вінниця : ВДПУ ім. М. Коцюбинського, 2006. - С. 8. 6. Зязюн И. А. Основы педагогического мастерства : [учебное пособие для высш. уч. заведений] / И. А. Зязюн. - К. : Вища школа, 1987. - 138 с. 7. Зязюн І. А. Педагогічна майстерність : [підручник для вищих навч. закл.] / І. А. Зязюн. - К. : Вища школа, 1997. - С. 35, 79-80. 8. Кремень В. Г. Освіта і наука в Україні - інноваційні аспекти. Стратегія. Реалізація. Результати / В. Г. Кремень. - К. : Грамота, 2005. - 448 с. 9. Полат Е. С. Новые педагогические и информационные технологии в системе образования : [учебное пособие] / Е.С.Полат, М. Ю. Бухаркина, М. В. Моисеева, А. Е. Петров. - М. : АСАВУЬШФ, 2001. - 272 с. 10. Роберт И. В. Толкование слов и словосочетаний понятийного аппарата информатизации образования / И. В. Роберт // Информатика и образование. - 2004. - № 5. - С. 22-29. 11. Спичко Н. А. Образовательная середа в обучении иностранным языкам / Н. А. Спичко // ИЯШ. - 2004. - №5. - C. 44-48. 12. Shin N. Direct and Indirect Effects of Online Learning on Distance Education / N. Shin, J. K. Y. Chan // British Journal of Educational Technology. - 2004. - Vol. 35. - № 3. - P. 275-288. 13. Трутнев А. Ю. Педагогические условия применения компьютерной технологии в процессе обучения студентов университета иностранному языку : автореф. дис. на соискание учен. степени канд. пед. наук / А. Ю. Трутнев ; МаГУ. - Магнитогорск, 2001. - 24 с. 14. Тряпельников А. В. Виртуальная образовательная среда в дистанционном обучении. Режим доступа: http://www.mapryal.org/vestnik/vestnik50/ problems.shtml 15. Щербаков А. И. Формирование личности учителя в системе высшего педагогического образования : автореф. дис. д-ра пед. наук / А. И. Щербаков. - Л., 1978. -25 с. 